\section{SOLOMON ISLANDS}

Area: 29,785 sq. $\mathrm{km}$

Population: 234,000

Capital: Honiara

Governor-General: Sir Baddeley Devisi Minister for Home Affairs: Kamilio Teke

The Solomons' Constabulary was formed in about 1910, and assumed its present name in 1950.

The Solomon Islands Police Force comprises four divisions, which correspond to the country's administrative districts:

Central - HQ Honiara

\author{
Eastern - HQ Kirakira \\ Malaita - HQ Auki \\ Western - HQ Gizo
}

The police force is headed by a Chief of Police and Prisons, also responsible for the Prison Service and the Fire Brigade.

The police force has paramilitary capability, and fulfills the role of a defence force (there is no army). It is also in charge of maintaining law and order and preventing and detecting crime. Its personnel strength is about 380 ; most other ranks are Solomon Islanders, with a diminishing proportion of Fijians. The British commissioned officers are being replaced by natives promoted from the ranks. There is a Police Training School at Honiara, but officers often graduate abroad - in the UK, Fiji and Papua New Guinea.

Solomon Islands Police Force Headquarters, Honiara Police Training School, Honiara 